University of Nebraska - Lincoln

DigitalCommons@University of Nebraska - Lincoln

Publications from USDA-ARS / UNL Faculty

U.S. Department of Agriculture: Agricultural

Research Service, Lincoln, Nebraska

2011

Phytotoxicity of Antofine from Invasive Swallow-Worts

Donna M. Gibson

USDA-ARS, Donna.Gibson@ars.usda.gov

Stuart B. Krasnoff

USDA-ARS

Jeromy Biazzo

USDA-ARS

Lindsey Milbrath

USDA-ARS

Follow this and additional works at: https://digitalcommons.unl.edu/usdaarsfacpub

Gibson, Donna M.; Krasnoff, Stuart B.; Biazzo, Jeromy; and Milbrath, Lindsey, "Phytotoxicity of Antofine from Invasive Swallow-Worts" (2011). Publications from USDA-ARS / UNL Faculty. 1250.

https://digitalcommons.unl.edu/usdaarsfacpub/1250

This Article is brought to you for free and open access by the U.S. Department of Agriculture: Agricultural Research Service, Lincoln, Nebraska at DigitalCommons@University of Nebraska - Lincoln. It has been accepted for inclusion in Publications from USDA-ARS / UNL Faculty by an authorized administrator of DigitalCommons@University of Nebraska - Lincoln. 


\title{
Phytotoxicity of Antofine from Invasive Swallow-Worts
}

\author{
Donna M. Gibson • Stuart B. Krasnoff • \\ Jeromy Biazzo $\cdot$ Lindsey Milbrath
}

This article is a U.S. government work, and is not subject to copyright in the United States.

Received: 4 February 2011 /Revised: 26 June 2011 / Accepted: 28 June 2011 /Published online: 8 July 2011

(C) Springer Science+Business Media, LLC (outside the USA) 2011

\begin{abstract}
Pale swallow-wort (Vincetoxicum rossicum) and black swallow-wort (V. nigrum) are two emerging invasive plant species in the northeastern United States and southeastern Canada that have shown rapid population expansion over the past 20 years. Using bioassay-guided fractionation, the known phytochemical phenanthroindolizidine alkaloid, (-)-antofine, was identified as a potent phytotoxin in roots, leaves, and seeds of both swallow-wort species. In seedling bioassays, $(-)$-antofine, at $\mu \mathrm{M}$ concentrations, resulted in greatly reduced root growth of Asclepias tuberosa, A. syriaca, and Apocynum cannabinum, three related, native plant species typically found in habitats where large stands of swallow-wort are present. In contrast, antofine exhibited moderate activity against lettuce, and it had little effect on germination and root growth of either black or pale swallow-wort. In disk diffusion assays, antifungal activity was observed at $10 \mu \mathrm{g}$ and $100 \mu \mathrm{g}$, while antibacterial activity was seen only at the higher level. Although both swallow-wort species display multiple growth and reproductive characteristics that may play an important role in their invasiveness, the presence of the highly bioactive phytochemical (-)-antofine in root and seed tissues indicates a potential allelopathic role in swallow-worts' invasiveness.
\end{abstract}

Key Words Antofine · Phytotoxin · Swallow-worts · Vincetoxicum · Cynanchum - Allelopathy Invasiveness . Allelopathic potential

D. M. Gibson $(\bowtie) \cdot$ S. B. Krasnoff $\cdot$ J. Biazzo $\cdot$ L. Milbrath USDA, Agricultural Research Service,

Biological Integrated Pest Management Research Unit,

Robert W. Holley Center for Agriculture and Health,

Tower Road,

Ithaca, NY 14853, USA

e-mail: Donna.Gibson@ars.usda.gov

\section{Introduction}

Two emerging invasive plant species in the northeastern United States and southeastern Canada are pale swallowwort [Vincetoxicum rossicum (Kleopow) Barbarich = Cynanchum rossicum (Kleopow) Borhidi] and black swallow-wort $[$ V. nigrum (L.) Moench $=C$. louiseae Kartesz \& Gandhi]. Both exist as herbaceous, perennial, twining vines and are related to milkweeds (Apocynaceae, subfamily Asclepiadoideae). Pale swallow-wort is native to the Ukraine and European Russia and possesses pink to maroon flowers, whereas black swallow-wort is native to southwestern Europe and bears dark purple to black flowers (Markgraf, 1972). These species were introduced into North America, probably as ornamentals, in the mid- to late-1800s, but not until the 1970's were concerns raised about the invasive potential of swallow-worts (Pringle, 1973). The last 20 years have seen a rapid expansion of both species (Lawler, 2000; DiTommaso et al., 2005b), which are currently reported in 21 U.S. states from New England to Maryland and west to Nebraska and Kansas, with an additional report from California, and the Canadian provinces of Ontario and Quebec (Kartesz, 1999; DiTommaso et al., 2005b; USDA 2009). The primary infestations are in New England, New York, and Ontario, and both species are listed as noxious weeds or prohibited invasive species in Vermont, New Hampshire, Massachusetts, and Connecticut (USDA 2009).

Both pale and black swallow-wort have multiple growth and reproductive characteristics that may play a role in their invasiveness. Swallow-wort vines can grow 1-2 m or more during the growing season, producing dense, tangled masses of vines that climb up and over supporting vegetation (Christensen, 1998; Douglass et al., 2009). Stand densities can average 134 stems per $\mathrm{m}^{2}$ and 1800 
seedlings per $\mathrm{m}^{2}$ (Smith et al., 2006). Large stands reportedly exclude most other vegetation, including the related milkweeds, and are encroaching on at least five threatened or endangered species in New York and New England and on the globally-rare alvar communities in Ontario and New York (Haribal and Renwick, 1998; Lawler, 2000; Tewksbury et al., 2002; Douglass et al., 2009). Perennating buds produced on the rootstock give rise to one or more herbaceous stems in the spring, and additional buds will sprout if stems are damaged (DiTommaso et al., 2005b). Flowering is indeterminate, extending from mid-May into August, and seeds bear an apical tuft of hairs, which aids in long-distance dispersal (Ladd and Cappuccino, 2005). Both swallow-wort species are self-compatible and can self-pollinate or are cross-pollinated by insects (Lumer and Yost, 1995; St. Denis and Cappuccino, 2004). Seed production can be prolific in high-light environmentsaround 32,000 seeds per $\mathrm{m}^{2}$ for high density stands of pale swallow-wort, and seeds are polyembryonic, containing 18 embryos (Cappuccino, 2004; DiTommaso et al., 2005a; Smith et al., 2006). Polyembryony may contribute to enhanced seedling establishment and survival rates, which can be over $50 \%$ for pale swallow-wort (DiTommaso et al., 2005a; Ladd and Cappuccino, 2005; Hotchkiss et al., 2008). Both species are drought tolerant and can grow in soils of a wide range of pH (DiTommaso et al., 2005b; Magidow et al., 2008). Pale swallow-wort also is shade tolerant, although in heavily shaded areas, little reproduction by seed occurs (Smith et al., 2006; Hotchkiss et al., 2008).

What is not clear is whether allelopathy also plays a role in the invasiveness of swallow-wort. Members of the Apocynaceae (including the Asclepiadoideae) are regarded as poisonous to humans and other mammals (Wiegrebe et al., 1970; Haznagy and Toth, 1973; Haeggstrom, 1990). In North America, swallow-wort plants sustain minimal damage from herbivory, as deer rarely browse them and few arthropod herbivores feed on them (Christensen, 1998; DiTommaso et al., 2005b; Ernst and Cappuccino, 2005; Milbrath, 2010).

Phenanthroindolizidine alkaloids, primarily (-)-antofine and antofine oxide, as well as several less abundant derivatives, have been isolated from the roots and aerial parts of $V$. hirundinaria Medik. (Wiegrebe et al., 1969; Lavault et al., 1994; Staerk et al., 2000; Staerk et al., 2002). $(-)$-Antofine also has been reported from root tissues of $V$. pumilum Dcne. (Staerk et al., 2005) and the aerial parts of black swallow-wort (Capo and Saa, 1989). (-)-Antofine and its derivatives, including antofine oxide, possess antifungal, antibacterial, and cytotoxic activity due to potent inhibition of protein and nucleic acid synthesis and G2/M cell cycle arrest (Ferenczy et al., 1965/1966; Rao and Venkatachalam, 2000; Staerk et al., 2002; LEE et al., 2003). Root extracts of pale swallow-wort have phytotoxic and antifungal properties
(Cappuccino, 2004); antofine was identified as the antimicrobial agent, while the component(s) responsible for phytotoxic or antifeedant activity has not been identified (Mogg et al., 2008). Similar phytotoxic effects of both root exudates and tissue leachates from pale and black swallowwort on lettuce and butterfly milkweed root growth recently have been reported (Douglass et al., 2011).

We undertook this study to determine if specific phytochemical constituents from the swallow-worts possess phytotoxic activity, a necessary step to evaluate whether allelopathy could play a role in swallow-worts' ability to displace native plant species in the environment. We herein report that the known phytochemical antofine is present in root, shoot, and leaf, and seed extracts of both pale and black swallow-wort, and that it has significant phytotoxicity against some related native plant species with little effect against pale or black swallow-wort germination and root development.

\section{Methods and Materials}

Plant Material Five plants of pale swallow-wort were excavated from Robert G. Wehle State Park, Jefferson Co., New York, in May 2005, and placed into a cooler for transport to the laboratory where the roots (with stems attached) were rinsed in several volumes of water to remove remaining soil. After removal of the stem and crown area, roots were weighed, frozen at $-20^{\circ} \mathrm{C}$, and then lyophilized to dryness and stored at $-20^{\circ} \mathrm{C}$ until extracted. Rootstocks of black swallow-wort were excavated from Bear Mountain State Park, Rockland Co., New York, in September 2005. They were held under refrigeration until January 2006 and then grown in a greenhouse for 4 mo until being harvested and prepared as noted above. For seed extractions, pale swallow-wort seed was collected in August 2008 from fields in Great Gully Preserve, (Cayuga Co.), New York, and black swallow-wort seed was collected in August 2008 from fields in Bear Mountain State Park, (Rockland Co.), New York. After pods were dried and crushed to release seeds, the majority of pod and pappus materials were removed by hand vacuum, and then seeds were sieved using mesh sizes of 30/64", 25/64", 19/64", 15/ 64", 11/64", 9/64", 7/64", and 5/64." Filled pale swallowwort seed was collected on the 7/64" sieve, while filled black swallow-wort seed was collected on the 11/64" and 9/ $64 "$ sieves. Cleaned seeds were stored at $4^{\circ} \mathrm{C}$ until use.

Seed Collections for Laboratory Bioassays For initial tests of phytotoxicity from crude swallow-wort extracts, seeds were obtained from the following sources: lettuce (Lactuca sativa L. cv. black-seeded Simpson) from a local gardener's supply store; black swallow-wort, Bear Mountain State 
Park, Rockland Co., New York, summer 2005; pale swallow-wort, Great Gully Preserve, Cayuga Co., New York, summer 2005; Asclepias syriaca L. (common milkweed), Great Gully Preserve, Cayuga Co., New York, fall 2005; Asclepias tuberosa L. (butterfly milkweed), Clark Reservation State Park, Jamesville, Onondaga Co., New York, fall 2005; Apocynum cannabinum L. (Indianhemp), Great Gully Preserve, Cayuga Co., New York, fall 2005.

For phytotoxicity tests with purified antofine, seeds were obtained from the following sources: black swallow-wort, Bear Mountain State Park, Rockland Co., New York, fall 2008; pale swallow-wort, Great Gully Preserve, Cayuga Co., New York, fall 2008; A. syriaca, Everwilde Farms, Inc., Bloomer, WI, USA; A. tuberosa, Everwilde Farms, Inc., Bloomer, WI, USA; A. cannabinum, Great Gully Preserve, Cayuga Co., New York, fall 2008.

All seed, except lettuce, was air-dried, cleaned, and stored dry in sealed containers under refrigeration $\left(4^{\circ} \mathrm{C}\right)$ for approximately 2 mo prior to stratification. To stratify seed for bioassays, approximately $5 \mathrm{~g}$ of seeds were wrapped in moist, brown paper toweling, and then stored in sealed glass jars with rubber gaskets or sealed petri dishes for 2 3 mo at $4^{\circ} \mathrm{C}$.

Seedling Root Growth Bioassay Solutions were applied in $1.0 \mathrm{ml}$ methanol to evenly coat the bottom of $10 \times 10 \mathrm{~cm}$ square Petri plates. After solvent evaporation $(30 \mathrm{~min})$, $20 \mathrm{ml}$ of $1.6 \%$ agarose were pipetted into each plate, agitated briefly by hand, and set to cool for $1 \mathrm{~h}$ at $22^{\circ} \mathrm{C}$; tested concentrations are given as amount $/ \mathrm{ml}$ agarose. Seeds were located in a row of 15 on the surface of each plate ca. $20 \mathrm{~mm}$ from the "top" edge of the plate with the root-ends all pointed in the same direction. Plates were covered, sealed with parafilm, and stored upright (with root-ends pointed down) in a chamber with a thermoperiod of $25: 20^{\circ} \mathrm{C}$ and photoperiod of 14:10 hL:D. Root lengths were measured typically at 7 and $14 \mathrm{~d}$. Two plates of 15 seeds each were used for each dosage of each compound, with each assay independently replicated at least twice. Measurements were averaged for each level, and \% root length was calculated relative to the average root length observed on the methanol only control -treated plates.

Extraction of Swallow-Wort Plant Materials For initial phytotoxicity testing, approximately $10 \mathrm{~g}$ either of freezedried roots or shoot/leaf material of pale and black swallow-wort were sequentially extracted with hexane, dichloromethane, ethanol, and water. Each fraction was dried, and then reconstituted in methanol at $40 \mathrm{mg} / \mathrm{ml}$ and assayed for phytoxicity against lettuce seeds. For larger scale preparations and for chemical analysis, freeze-dried plant materials were extracted with 10 vol (v/wt) of dichloromethane:methanol (1:1). After gentle stirring for $24 \mathrm{~h}$, the solvent was removed by filtration, and the residual powder was re-extracted for an additional $24 \mathrm{~h}$ with $10 \mathrm{vol}$ $(\mathrm{v} / \mathrm{wt})$ of dichloromethane:methanol (1:1), treated as above, and then both extracts were combined, and dried in vacuo by rotary evaporation. Seed samples ( $2 \mathrm{~g}$ per replicate) were ground to a fine powder in a coffee mill, and then extracted as above. Extracts were combined and filtered through 2 layers of Whatman No. 1 filter paper and then dried in vacuo by rotary evaporation.

Preparative TLC Silica plates (Baker-500 $\mu \mathrm{M}$ thickness; $25 \times 25 \mathrm{~cm}$ ), loaded with $6 \mathrm{mg}$ of pale swallow-wort extract, were used to preparatively separate the constituents of the active root fractions, using ethyl acetate:methanol (60:40) as a developing solvent. Bands observed under short and long-wave UV were recombined into seven fractions by scraping and elution in $\mathrm{MeOH}$. Fractions were reanalyzed (Baker-40- $\mu \mathrm{m} ; 25 \times 0.5 \mathrm{~cm}$ ) for confirmation of $\mathrm{Rf}$ prior to testing for phytotoxicitiy against lettuce seedlings.

Purification of Active Phytotoxic Fraction Freeze-dried root material (approximately $50 \mathrm{~g}$ ) was ground to a fine powder in a coffee mill, and then extracted in dichloromethane:methanol (1:1) as described above to yield $3.3 \mathrm{~g}$ of a brownish-yellow gum. The crude extract then was partitioned between dichloromethane $(1 \mathrm{vol})$ and water $(2$ vol), the organic layer was dried over anhydrous $\mathrm{Na}_{2} \mathrm{SO}_{4}$, and the solvent removed in vacuo to afford an oily yellowish-brown residue $(0.76 \mathrm{~g})$ that retained all of the original activity of the crude extract. This material was dissolved in dichloromethane and chromatographed on silica gel (Baker $40-\mu \mathrm{m} ; 300 \times 25 \mathrm{~mm}$ ), eluted with $400 \mathrm{ml}$ each of $100 \%$ dichloromethane, 1, 2, 5, 10, 20, and $50 \%$ methanol in dichloromethane, and $100 \%$ methanol. The $10 \% \mathrm{MeOH}$ fraction, which exhibited the greatest phyotoxic activity, was re-chromatographed on silica column

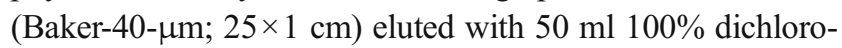
methane, $200 \mathrm{ml}$ each of $10 \%, 20 \%$, and $50 \%$ methanol in dichloromethane. Phytotoxic activity was recovered in the $10 \%$ methanol fraction that afforded (-)-antofine (approx. $90 \%)(22.3 \mathrm{mg})$. At each step in the purification, fractions were monitored using TLC on silica with ethyl acetate:methanol $(60: 40)$ as the mobile phase. Semi-preparative HPLC was used to obtain purified material for spectral analysis.

Antimicrobial Bioassay (-)-antofine was tested in a disk diffusion assay against bacterial strains (Escherichia coli, Bacillus cereus, and Bacillus subtilis) grown on nutrient agar plates $(9 \mathrm{~cm})$ and against fungal target strains (Colletotrichum acutatum, Fusarium graminearum, Beauveria bassiana, and Metarhizium anisopliae) grown on potato 
dextrose agar plates. Plates spread with $0.5 \mathrm{ml}$ aliquots of a liquid bacterial culture grown for $24 \mathrm{~h}$ in nutrient broth or with $0.5 \mathrm{ml}$ of a fungal spore suspension $\left(1 \times 10^{6}\right.$ spores $\left./ \mathrm{ml}\right)$ were allowed to dry for $1 \mathrm{~h}$. Test samples were applied to 4-mm filter paper disks in $10 \mu \mathrm{l}$ methanol, air-dried for $1 \mathrm{~h}$, and then placed on test plates. Zones of inhibition were measured after $48 \mathrm{~h}$. Antofine was tested at 10 and $100 \mu \mathrm{g} / \mathrm{disk}$. Methanol was used as a negative control $(10 \mu \mathrm{l})$; positive controls used were iturin $(10 \mu \mathrm{g})$ or filipin $(10 \mu \mathrm{g})$ (Sigma) applied in methanol for fungal assays and commercial disks (Sigma) pretreated with ampicillin $(10 \mu \mathrm{g})$ or erythromycin $(15 \mu \mathrm{g})$ for bacterial assays.

HPLC Analysis Analytical HPLC was carried out by a modification of the method of Cui et al. (2004) employing a reversed phase C18 column (Varian, $5 \mu \mathrm{m}, 250 \times 4.6 \mathrm{~mm}$ ), premixed isocratic mobile phase of methanol: $20 \mathrm{mM}$ ammonium acetate $(1: 1 \mathrm{v} / \mathrm{v})$, flow rate of $1 \mathrm{ml} / \mathrm{min}$, with primary detection by UV at $260 \mathrm{~nm}$ and a wavelength scan of 200 to $350 \mathrm{~nm}$. Retention time (RT) of antofine under these conditions was $6.5 \mathrm{~min}$, with limit of detection $(\mathrm{s} / \mathrm{n}=10)$ established at $0.2 \mu \mathrm{g}$ on-column. The peak corresponding to antofine oxide $(\mathrm{RT}=6.0 \mathrm{~min})$ possessed an almost identical photo diode array (PDA) spectrum and was quantified using peak area equivalences to antofine. Semi-preparative HPLC was carried out using a (ODS) 3 column (end capped C18, Phenomenex, $5 \mu \mathrm{m}, 250 \times 4.6 \mathrm{~mm}$ ), premixed isocratic mobile phase of methanol: $20 \mathrm{mM}$ ammonium acetate $(3: 2 \mathrm{v} / \mathrm{v})$, flow rate of $1 \mathrm{ml} / \mathrm{min}$, with primary detection by UV at $260 \mathrm{~nm}$ and a wavelength scan of 200 to $350 \mathrm{~nm}$, that allowed longer retention times for peak collection of the phytotoxic components.

Spectrometric Measurements Low-resolution electrospray ionization mass spectra (LRESIMS) spectra were acquired by infusion of methanolic solutions at $5 \mu \mathrm{l} / \mathrm{min}$ by a syringe pump (Harvard apparatus) into a Micromass ZMD-4000 spectrometer. Positive-ion-mode spectra were acquired with capillary cone voltages of $3.2 \mathrm{kV}$ and $40 \mathrm{~V}$, respectively; negative-ion-mode spectra were acquired with capillary and cone voltages of $4.0 \mathrm{kVand} 20 \mathrm{~V}$, respectively. High-resolution electrospray ionization mass spectrometry (HRESIMS) data were acquired by the mass spectrometry facility at the University of Illinois, Urbana Campus, USA.

Statistical Analysis Data was analyzed using JMP ${ }^{\circledR}$ statistical software, version 8.0.1; Tukey-Kramer's post-hoc test $(P<$ 0.05 ) was used for comparisons within treatments of solventtissue extracts and for initial effects on plant species. Doseresponse curves were fit to a 4-parameter logistic model (Streibig et al., 1993), and $\mathrm{I}_{50}$ values were estimated from these curves.

\section{Results}

Concentration-dependent Phytotoxicity of Swallow-wort Extracts Sequential extraction of root and combined leaf and shoot materials from pale swallow-wort followed by bioassay testing using lettuce seedlings at $0.5 \mathrm{mg} / \mathrm{ml}$ applied dose revealed that the phytotoxic activity resided primarily in the dichloromethane and ethanol fractions (Fig. 1), which represented $1.5 \%$ and $2.5 \%$, respectively, of the root dry weight, and $1.8 \%$ and $3.8 \%$, respectively, of the dry weight of the shoot/leaf material. For further analysis and subsequent purification of the phytotoxic principles, both pale and black swallow-wort root tissue were extracted with dichloromethane: methanol (1:1). To assess activity against seed germination and root growth of native plant species, extracts were tested at $0.25 \mathrm{mg} / \mathrm{ml}$ and $1 \mathrm{mg} / \mathrm{ml}$. Inhibitory activity of pale swallow-wort extract was evident at both levels against a number of native plant species that co-occur with invasive swallow-worts (Fig. 2). Black swallow-wort extract was not as potent, showing activity only at the $1 \mathrm{mg} / \mathrm{ml}$ level (data not shown). Little activity was noted with either extract, when tested against itself or the congeneric species (Fig. 2).

Identification of the Phytotoxic Constitutent of Pale and Black Swallow-Wort

Phytotoxic activity was confined to a single TLC band $(\mathrm{Rf}=.62)$ visible as a dark spot under long wave UV that represented less than $1 \%$ of the original extract. Combined

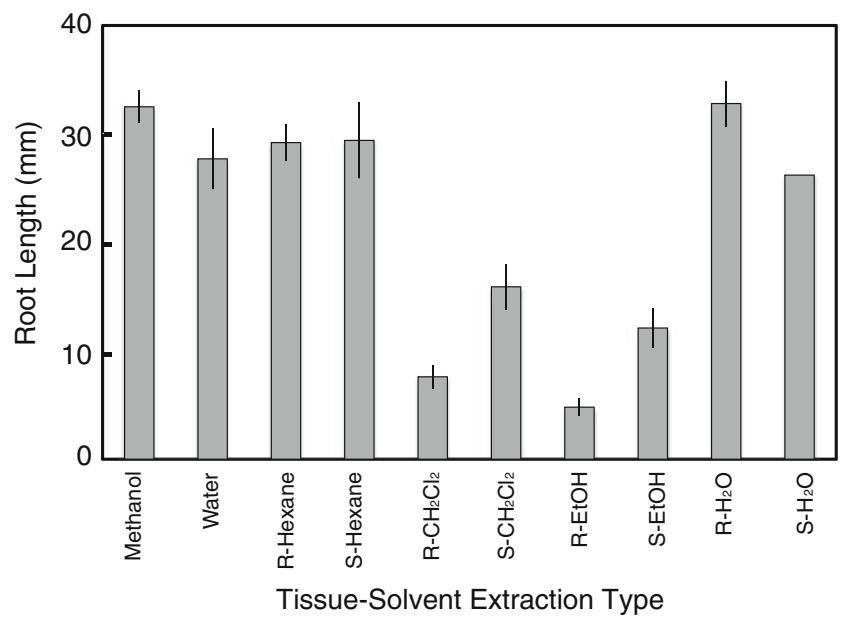

Fig. 1 Effect of sequential extractions of root and shoot/leaf tissues of pale swallow-wort on lettuce seedling root length. Measurements were taken at 1 wk of growth with a thermoperiod of $25: 20^{\circ} \mathrm{C}$ and photoperiod of 14:8 hL:D using methanol and water as negative controls with $0.5 \mathrm{mg} / \mathrm{ml}$ applied dose of each extract. Data plotted are the mean ${ }^{ \pm} \mathrm{SE},(N=30) . \mathrm{R}=$ root tissue; $\mathrm{S}=$ shoot and leaf tissue 


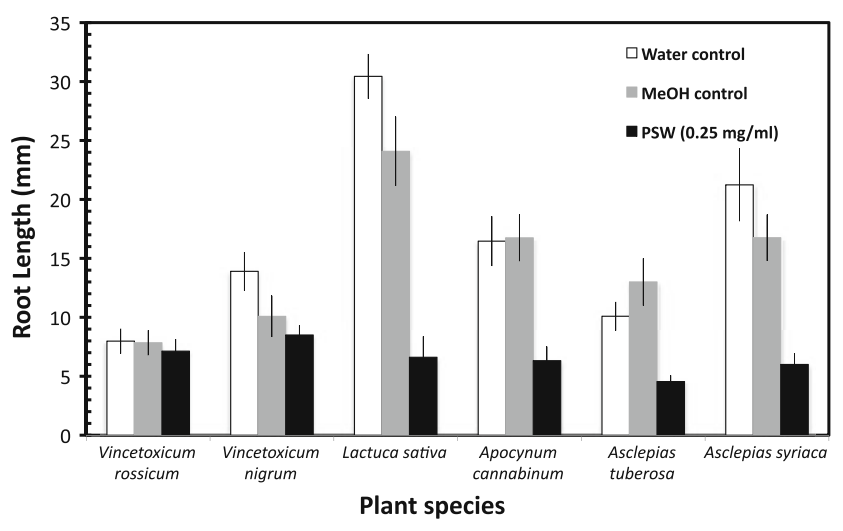

Fig. 2 Effect of pale swallow-wort (PSW) root extract at $0.25 \mathrm{mg} / \mathrm{ml}$ applied dose on root lengths of plant seedlings measured at 1 wk. Plates were incubated with a thermoperiod of $25: 20^{\circ} \mathrm{C}$ and photoperiod of 14:8 hL:D. Data plotted are the mean ${ }^{ \pm} \mathrm{SE},(N=30)$

fractions from silica gel chromatography were monitored by dose equivalence bioassay and by analytical TLC to monitor the elution of the major phytotoxic principle. Phytotoxic activity was recovered in the $10 \%$ methanol:dichloromethane fraction, representing $0.05 \%$ dry wt of the starting material.

LRESIMS analyses of the phytotoxic fraction indicated the presence of a major component with a molecular weight of $m / z[\mathrm{M}+\mathrm{H}]+=364$, which is consistent with the major phenanthroindolizidine alkaloid, (-)-antofine, previously identified from shoot tissues of $V$. rossicum and V. nigrum and related Vincetoxicum species (Wiegrebe et al., 1970; Capo and Saa, 1989; Staerk et al., 2000, 2005; LEE et al., 2003), and recently reported from root extracts of $V$. rossicum (Mogg et al., 2008). Semi-preparative HPLC was used to collect one minor $(\mathrm{RT}=6.5 \mathrm{~min}$ ) and two major peaks (RTs $=8.0$ and $13.5 \mathrm{~min}$ ), all of which had elution and UV spectral characteristics consistent with published values for antofine (Wiegrebe et al., 1969; Cui et al., 2004). The minor peak was putatively identified as hydroxy antofine oxide based on LRESIMS of $\mathrm{m} / z[\mathrm{M}+\mathrm{H}]+=$ 396, and was not examined further. HRESIMS data for the major component eluting at $\mathrm{RT}=13.5 \mathrm{~min}$ was consistent with the molecular formula $\mathrm{C}_{23} \mathrm{H}_{26} \mathrm{NO}_{3}$ (for $[\mathrm{M}+\mathrm{H}]^{+}$, obsd $\mathrm{m} / \mathrm{z}$ 364.1911; calcd 364.1913). The component eluting at $\mathrm{RT}=8.0 \mathrm{~min}$, with a molecular weight of $\mathrm{m} / z[\mathrm{M}+\mathrm{H}]+=380$ on LRESIMS, was consistent with antofine oxide, another known compound reported from Vincetoxicum species. HRESIMS data for this component was consistent with the molecular formula $\mathrm{C}_{23} \mathrm{H}_{26} \mathrm{NO}_{4}$ (for $[\mathrm{M}+\mathrm{H}]^{+}$, obsd $\mathrm{m} / \mathrm{z}$ 380.1860; calcd 380.1862). The purified active fraction represented $0.05 \%$ (dry wt basis) from pale swallow-wort roots and $0.015 \%$ from black swallow-wort roots, similar to concentrations of antofine reported from $\mathrm{V}$. pumilum and V. rossicum root tissue (Staerk et al., 2005; Mogg et al., 2008).
Phytochemical Activity of Antofine Activity of the antofine preparation was tested over a concentration range from 0.1 to $75 \mu \mathrm{g} / \mathrm{ml}$ using the seedling bioassay system. Root growth of all tested plant species was inhibited by antofine to some degree, but differential sensitivity to the phytotoxin was evident when activity was tested against three native plant species. Little inhibition of root growth of pale and black swallow-wort seedlings was seen up to a concentration of $75 \mu \mathrm{g} / \mathrm{ml}$, while lettuce was moderately affected, producing an $\mathrm{I}_{50}=12.5 \mu \mathrm{g} / \mathrm{ml}(34 \mu \mathrm{M})$ (Fig. 3). In contrast, root growth of $A$. tuberosa and $A$. syriaca was markedly inhibited by antofine, with $\mathrm{I}_{50}=1.25$ and $3.1 \mu \mathrm{g} / \mathrm{ml}(3.4$ and $8.6 \mu \mathrm{M})$, respectively (Fig. 4). Apocynum cannabinum root growth also was inhibited but at slightly higher concentrations $\left(\mathrm{I}_{50}=\right.$ $3.75 \mu \mathrm{g} / \mathrm{ml} ; 10.3 \mu \mathrm{M}$ ). Extensive browning of the root tip was visible on all of these native species, with little to no growth by $25 \mu \mathrm{g} / \mathrm{ml}(69 \mu \mathrm{M})$. In bioassays against pale or black swallow-wort, root growth was only slightly reduced at the highest concentration of $75 \mu \mathrm{g} / \mathrm{ml}(206 \mu \mathrm{M})$ with little visible tissue damage.

Detection of (-)-Antofine in Seeds of Pale and Black Swallow-Wort HPLC and LRESIMS data indicated that antofine was present in seeds of both black and pale swallow-wort seeds, a previously undocumented source of phenanthroindolizidine alkaloids, which have been reported only from roots and aerial portions of Vincetoxicum. As assessed by HPLC, antofine was detectable at concentrations of $1.10 \%$ (fresh wt) and $0.45 \%$ in seeds of pale and black swallow-wort, respectively.

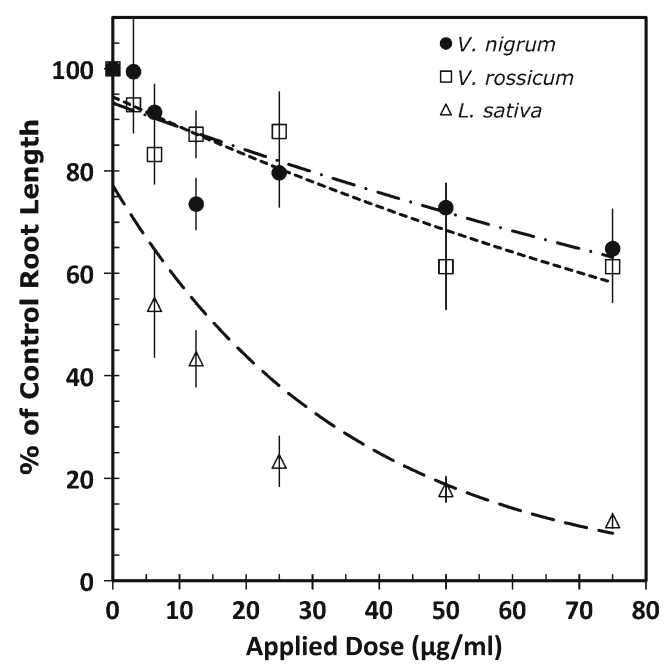

Fig. 3 Dose response profiles, plotted as a percentage (\%) of the control root length in the absence of antofine, of Vincetoxicum nigrum, V. rossicum, and Lactuca sativa seeds germinated in the presence of varying concentrations of antofine. Plates were incubated with a thermoperiod of $25: 20^{\circ} \mathrm{C}$ and photoperiod of $14: 8 \mathrm{hL}: \mathrm{D}$, and scored after $14 \mathrm{~d}$. Data plotted are the mean $\pm \mathrm{SE},(N=30)$ 


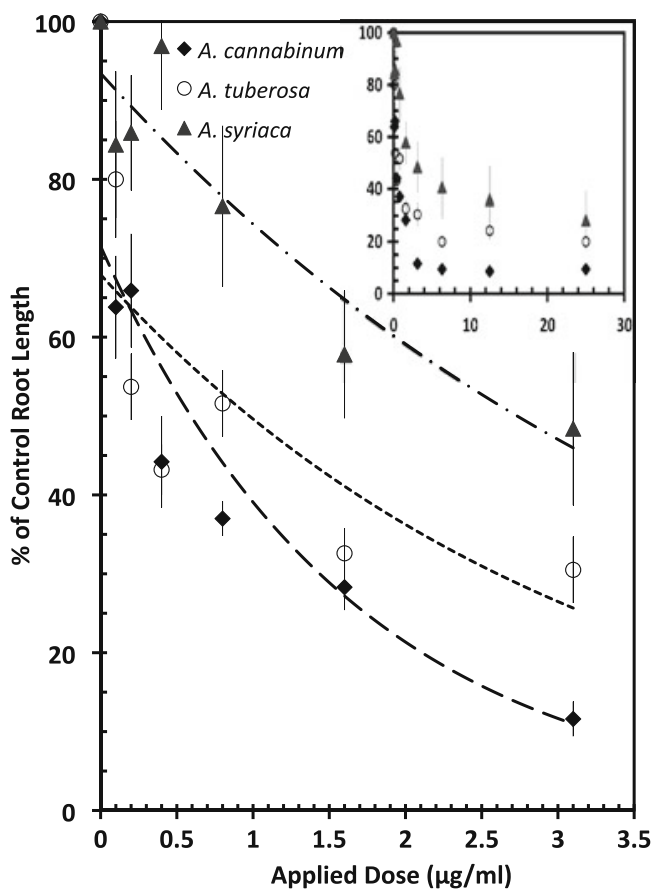

Fig. 4 Dose response profiles, plotted as a percentage (\%) of the control root length in the absence of antofine, of Apocynum cannabinum, Asclepias tuberosa, and A. syriaca seeds germinated in the presence of varying concentrations of antofine. Plates were incubated with a thermoperiod of $25: 20^{\circ} \mathrm{C}$ and photoperiod of 14:8 hL:D, and scored after $14 \mathrm{~d}$. Inset shows response under an expanded range of concentrations, with little/no root growth evident at concentrations $>25 \mu \mathrm{g} / \mathrm{ml}$ applied dose. Data plotted are the mean \pm SE, $(N=30)$

Antibiotic Activity At 48 h, clear zones of antifungal activity were evident from the $100 \mu \mathrm{g}$ antofine treatment similar to that observed with the positive controls (Table 1). Much smaller zones were visible with the $10 \mu \mathrm{g}$ antofine treatment, at levels consistent with previous reports (Baumgartner et al., 1990; Mogg et al., 2008). The antibacterial activity was less pronounced at the same concentrations; no activity was observed with $10 \mu \mathrm{g}$ antofine, while only small clear zones of inhibition ( $2 \mathrm{~mm}$ ) were observed at the higher level in comparison to the large kill zones from all positive controls (Table 1).

\section{Discussion}

We undertook the current study to assess the potential contribution of phytotoxins to swallow-worts' invasiveness through allelochemical interactions. Among the many hypotheses advanced to understand the dynamics of invasive species, the "novel weapons" or "allelopathic advantage against resident species" (AARS) hypothesis (Bais et al., 2003; Callaway and Ridenour, 2004) is based on the production of allelochemicals in sufficient quantities by the invasive species to produce phytotoxicity in a group of susceptible, or non-adapted, plants. This hypothesis was originally based on a series of observations that Centauraea diffusa and $C$. maculosa were at a competitive advantage relative to native species in the invaded range compared to their native range (Callaway and Aschehoug, 2000; Bais et al., 2003). Debate about this hypothesis continues because of conflicting estimates of $( \pm)$ catechin levels from Centaurea species in soils that call into question whether concentrations are sufficient to cause phytotoxicity (Blair et al., 2005). Much of the original work has been discredited
Table 1 antimicrobial activity of (-)-antofine

$n t$ not tested

Test Organism

$\begin{array}{cr}\text { Metarhizium } & \text { Beauveria } \\ \text { acridum } & \text { bassiana }\end{array}$

Treatment

$-(-)$ antofine

$10 \mu \mathrm{g} \quad 5$

$100 \mu \mathrm{g} \quad 12$

Methanol $-10 \mu \mathrm{l} \quad 0$

iturin $-10 \mu \mathrm{g} \quad \mathrm{nt}$

filipin $-10 \mu \mathrm{g}$

$-(-)$ antofine

$10 \mu \mathrm{g}$

$100 \mu \mathrm{g}$

methanol $-10 \mu \mathrm{l}$

ampicillin $-10 \mu \mathrm{g}$

erythromycin $-15 \mu \mathrm{g}$

2

Escherichia coli

Bacillus cereus

$\begin{array}{ll}0 & 0 \\ 2 & 0 \\ 0 & 0 \\ 2 & 4 \\ 5 & 11\end{array}$

$\begin{array}{cc}\begin{array}{l}\text { Fusarium } \\ \text { graminearum }\end{array} & \begin{array}{c}\text { Colletotrichum } \\ \text { acutatum }\end{array}\end{array}$

Inhibition Zone (mm)

1

$1+5$

0

nt nt

5

Bacillus subtilis

0

0

4

11 
(see Blair et al., 2006; Norton et al., 2008; Duke et al., 2009); at least one paper has been withdrawn (Weir et al., 2003) and soil and exudate concentrations have been revised (Weir et al., 2009; Bais et al., 2010), leaving questions as to whether allelochemicals can contribute to invasiveness. Recent field evidence has indicated that root exudates containing $( \pm)$ catechin are allelopathic against species that co-occur in the invaded range, but do not cause a similar inhibitory effect in the native range (Thorpe et al., 2009). Some of these difficulties may be due to experimental problems with detection, extraction from various soil types, the possibility of pulsed releases, and stability of the compound in the soil (Inderjit et al., 2008a). The novel weapons hypothesis continues to be attractive given the numerous examples of allelopathic effects of exudates (Hierro and Callaway, 2003; Inderjit et al., 2008b) and the presence of novel chemistries in invasive exotic plants (Cappuccino and Arnason, 2006), although few chemicals have been tied specifically to an environmentally relevant allelopathic trait associated with invasiveness.

Previous observations have led to the suggestion that swallow-worts might affect rhizosphere dynamics through the production of allelochemicals. Shifts in arbuscular mycorrhizal fungi that benefit swallow-wort growth have been detected (Greipsson and DiTommaso, 2006; Smith et al., 2008). When evaluating potential Allee effects (latency in the rate of spread) in $V$. rossicum populations, Cappuccino (2004) noted the greater suppression of background vegetation by larger patches relative to smaller plant treatments. Others have suggested that purported allelochemicals could play a role in competitive plant interactions (DiTommaso et al., 2005b). Antofine was identified in $V$ rossicum root extracts and shown to have broad-spectrum antifungal activity (Mogg et al., 2008), but anti-feedant activity against sawfly larvae and masked birch caterpillar was attributed to an as-yet unidentified compound. Allelopathic activity from V. rossicum has been reported, but the chemistry involved was not identified (Cappuccino, 2004; Douglass et al., 2011).

This study extends the spectrum of antofine's bioactivity to include phytotoxicity which is especially potent against native asclepiads. We attributed phytotoxicity of root extracts of pale and black swallow-worts to the presence of (-)-antofine, an antimicrobial and cytotoxic phenanthroindolizidine alkaloid previously reported from Vincetoxicum species. The concentration of antofine in pale and black swallow-wort extracts correlates with the level of crude extract required for biological activity in seedling bioassays; in our preparations, pale swallow-wort root tissues had approximately four times the level of that found in black swallow-wort roots. We also documented antifungal and antibacterial activity of antofine at submilligram levels as shown previously, but we discovered that antofine also was biologically active at $\mu \mathrm{M}$ concentrations in seedling bioassays. Antofine demonstrated potent phytoxicity against a few native North American plant species that typically are found in areas being invaded by the nonnative swallow-worts, although there was little activity seen when tested against either pale or black swallow-wort. We also report the presence of antofine in seeds, at concentrations approximately 2-3 times higher than that detected in roots or aerial portions of the plant. All of these findings point to antofine, and perhaps antofine oxide and other closely related alkaloids also reported to have cytotoxic activity (Staerk et al., 2000, 2002, 2005), as potential candidate phytochemicals that could exhibit allelopathic effects on surrounding vegetation and rhizosphere dynamics. Our preliminary experiments using antofine-spiked soil indicate that antofine is capable of causing root growth inhibition but at higher concentrations than found in the seedling bioassay system. We anticipate that soil type and $\mathrm{pH}$ will affect adsorption, stability, and availability of antofine as a potential allelochemical, so experiments are underway to determine antofine concentrations in undisturbed rhizospheres as well as the efffective recovery rates as a function of soil type and extraction method.

Invasive plants typically exhibit a suite of attributes that collectively contribute to their invasiveness. In the case of the swallow-worts, their success as invasive weeds in the northeastern U.S. may be due, at least in part, to their high fecundity (Smith et al., 2006) and their ability to adapt to a variety of habitats (Sheeley and Raynal, 1996; DiTommaso et al., 2005b), leading to an displacement of native species within native and disturbed environments (Ladd and Cappuccino, 2005; Douglass et al., 2009). The disproportionate production of root biomass relative to aerial plant development in pale swallow-wort would provide significant advantages for obtaining nutrients (Cappuccino, 2004; Smith et al., 2006; Milbrath, 2008); once established in satellite populations, the plants exhibit profuse and aggressive growth that can alter the light canopy, among other environmental factors (DiTommaso et al., 2005b). Whether this active growth phase also involves allelochemical interactions that aid in the displacement of native populations is as yet unproven. This study provides laboratory evidence that the phytochemical properties of antofine could contribute to swallow-worts' invasiveness in non-native habitats. Future studies are needed to determine whether antofine and related compounds are present at sufficient levels within the soil and rhizosphere to cause physiological responses relevant to invasion ecology of pale and black swallow-wort populations.

Acknowledgments We gratefully acknowledge the technical assistance of Richard Vaughan for portions of this study. Mention of a trademark, proprietary product, or vendor does not constitute a guarantee or warranty of the product by the U.S. Department of Agriculture and does not imply its approval to the exclusion of other products or vendor that may also be suitable. 


\section{References}

Bais, H. P., Vepachedu, R., Gilroy, S., Callaway, R. M., and VIVANCO, J. M. 2003. Allelopathy and exotic plant invasion: from molecules and genes to species interactions. Science $301: 1377-1380$

Bais, H.P., Vepachedu, R., Gilroy, S., Callaway, R. M., and VIVANCO, J. M. 2010. Science 327: 781-corrections and clarifications.

Baumgartner, B., Erdelmeier, C. A. J., Wright, A. D., Rali, T., and STICHER, O. 1990. An antimicrobial alkaloid from Ficus septica. Phytochemistry 29:3327-3330.

Blair, A. C., Hanson, B. D., BrunK, G. R., Marrs, R. A., Westra, P., Nissen, S. J., and HufBauer, R. A. 2005. New techniques and findings in the study of a candidate allelochemical implicated in invasion success. Ecol. Lett. 8:1039-1047.

Blair, A. C., Nissen, S. J., BrunK, G. R., and Hufbauer, R. A. 2006. A lack of evidence for an ecological role of the putative allelochemical $( \pm)$-Catechin in spotted knapweed invasion success. J. Chem. Ecol. 32:2327-2331.

Callaway, R. M., and Aschehoug, E. T. 2000. Invasive plant versus their new and old neighbors: a mechanism for exotic invasion. Science 290:521-523.

Callaway, R. M., and Ridenour, W. M. 2004. Novel weapons: invasive success and the evolution of increased competitive ability. Front. Ecol. Environ. 2:436-443.

CAPO, M., and SAA, J. M. 1989. (-)-Antofine: A phenanthroindolizidine from Vincetoxicum nigrum. J. Nat. Prod. 52:389-390.

CAPPUCCINO, N. 2004. Allee effect in an invasive alien plant, pale swallow-wort Vincetoxium rossicum (Asclepiadaceae). Oikos 106:3-8.

CAPPUCCINO, N., and ARnASON, J. T. 2006. Novel chemistry of invasive exotic plants. Biol. Lett. 2:189-193.

Christensen, T. 1998. Swallowworts: The ecology and control of Vincetoxicum spp. Wildflower 14:21-25.

Cui, L., Abliz, Z., Xia, M., ZhaO, L., GaO, S., He, W., Xiang, Y., LIANG, F., and YU, S. 2004. On-line identification of phenanthroindolizidine alkaloids in a crude extract from Tylophora atrofolliculata by liquid chromatography combined with tandem mass spectrometry. Rapid Comm. Mass Spec. 18:184-190.

Ditommaso, A., Brainard, D. C., and Webster, B. R. 2005a. Seed characteristics of the invasive alien vine Vincetoxicum rossicum are affected by site, harvest date, and storage duration. Can. J. Bot. 83:102-110.

Ditommaso, A., Lawlor, F. M., and Darbyshire, S. J. 2005b. The biology of invasive alien plants in Canada.2. Cyanchum rossicum (Kleopow) Borhidi [= Vincetoxicum rossicum (Kleopow Barbar.] and Cyanchum louiseae (L.) Kartesz \& Gandhi [= Vincetoxicum nigrum (L.) Moench]. Can. J. Plant Sci. 85:243-263.

Douglass, C. H., Weston, L. A., and Ditommaso, A. 2009. Black and Pale Swallow-Wort (Vincetoxicum nigrum and V. rossicum): The Biology and Ecology of Two Perennial, Exotic and Invasive Vines. pp. 261-277 in INDERJIT, (ed). Management of Invasive Weeds. Springer, Dordrecht, The Netherlands.

Douglass, C. H., Weston, L. A., and Wolfe, D. 2011. Phytotoxicity and potential allelopathy in pale (Cynanchum rossicum) and black swallow-wort (C. nigrum). Invasive Plant Sci. Mgmt. 4:133-141.

Duke, S. O., Blair, A. C., Dayan, F. E., Johnson, R. D., Meepagala, K. M., Cook, D., and Bajsa, J. 2009. Is (-)Catechin a novel weapon of spotted knapweed (Centaurea stoebe)? J. Chem. Ecol. 35:141-153.

ERNST, C. M., and CAPPUCCINO, N. 2005. The effect of an invasive vine, Vincetoxicum rossicum (Asclepiadaceae), on arthropod populations in Ontario old fields. Biol. Invasions 7:417-425.
Ferenczy, L., Zsolt, J., Haznagy, A., Toth, L., and Szendrei, K. 1965/1966. Examinations of antifungal compounds of Cynanchum vincetoxicum (L.) Pers. Acta Micro. Acad. Sci. Hungary 12:337.

GrEIPSSON, S., and DitomMaso, A. 2006. Invasive non-native plants alter the occurrence of arbuscular mycorrhizal fungi (AMF) and benefit from that association. Ecol. Restor. 24(236-241).

HAEGGSTROM, C.-A. 1990. The influence of sheep and cattle grazing on wooded meadows in Cland, SW Finland. Acta Bot. Fennica 141:1-28.

HARIBAL, M., and RENwICK, J. A. A. 1998. Identification and distribution of oviposition stimulants for Monarch butterflies in hosts and nonhosts. J. Chem. Ecol. 24:891-894.

HAZNAGY, A., and ToTH, L. 1973. Isolation of some substances from the roots and leaves of Cyanchum vincetoxicum. IX. Pharmazie $28: 210-212$.

Hierro, J. L., and Callaway, R. M. 2003. Allelopathy and exotic plant invasions. Plant Soil 256:25-39.

Hotchisiss, E. E., DotommasO, A., Brainard, D. C., and Mohler, C. L. 2008. Survival and performance of the invasive vine Vincetoxicum rossicum (Apocynaceae) from seeds of different embryo number under two light environments. Amer. J. Bot. 95:447-453.

InderJit, Pollock, J. L., Callaway, R. M., and Holben, W. 2008a. Phytotoxic effects of $( \pm)$-catechin in vitro, in soil, and in the field. PLoS ONE 3:e2536.

InderJit, Seastedt, T. R., Callaway, R. M., Pollock, J. L., and KAUR, J. 2008b. Allelopathy and plant invasions: traditional, congeneric, and bio-geographical approaches. Biol. Invasions $10: 875-890$

KARTESZ, J. T. 1999. A synonymized checklist and atlas with biological attributes for the vascular flora of the United States, Canada, and Greenland. in J. T. KARTESZ and C. A. MEACHAM (eds). Synthesis of the North American Flora, Version 1.0. 1st ed. Chapel Hill, NC: North Carolina Botanical Garden.

LADD, D., and CAPPUCCINO, N. 2005. A field study of seed dispersal and seedling performance in the invasive exotic vine Vincetoxicum rossicum. Can. J. Bot. 83:1181-1188.

LaVault, M., Richomme, P., and Bruneton, J. 1994. New phenanthroindolizidine $\mathrm{N}$-oxides alkaloids isolated from Vincetoxicum hirundinaria Medic. Pharm. Acta Helvetiae 68:225-227.

LAWLER, F. M. 2000. Herbicidal Treatment of the Invasive Plant Cynanchum rossicum and Experimental Post Control Restoration of Infested Sites. Syracuse, NY: State University of New York. 78 p.

LEE, S. K., and NAM, G. A.; Herbentechn Inc., S. Korea, assignee. 2003. Antofine from Cyanchum paniculatum extracts. Korea patent KR 2003016774.

LUMER, C., and Yost, S. E. 1995. The reproductive biology of Vincetoxicum nigrum (L.) Moench (Asclepiadaceae), A Mediterranean weed in New York State. Bull. Torrey Bot. Club 122:15-23.

Magidow, L. C., Ditommaso, A., Ketterings, Q. M., and Milbrath, L. R. 2008. Does Soil pH Infuence Swallow-wort Distribution in its Current Range? Proc. Northeast. Weed Soc. p 21.

MARKGRAF, F. 1972. Vincetoxicum N.M. Wolf. pp. 71-73 in T. G. TUTIN, V. J. HEYWOOD, N. A. BURGES, D. M. MOORE, D. H. VALENTINE, S. M. WALTERS, and D. A. WEBB (eds). Flora Europeae. Cambridge University Press, Cambridge, UK.

MiLBRATH, L. R. 2008. Growth and reproduction of invasive Vincetoxicum rossicum and $\mathrm{V}$. nigrum under artificial defoliation and different light environments. Botany 86:1279-1290.

MiLBRATH, L. R. 2010. Phytophagous arthropods of invasive swallowwort vines (Vincetoxicum spp.) in New York. Environ. Entomol. 39:68-78.

Mogg, C., Petit, P., Cappuccino, N., Durst, T., Mckague, C., Foster, M., Yack, J. E., ARnAson, J. T., and SMith, M. L. 2008. Tests of the antibiotic properties of the invasive vine 
Vincetoxicum rossicum against bacteria, fungi and insects. Biochem. System. Ecol. 36:383-391.

Norton, A. P., Blair, A. C., Hardin, J. G., Nissen, S. J., and BRUNK, G. R. 2008. Herbivory and novel weapons: no evidence for enhanced competitive ability or allelopathy induction of Centaurea diffusa by biological controls. Biol. Invasions 10:7988.

PrINGLE, J. S. 1973. The spread of Vincetoxicum species (Asclepiadaceae) in Ontario. Can. Field-Natural. 87:27-33.

RAO, N., and VENKATACHALAM, S. R. 2000. Inhibition of dihydrofolate reductase and cell growth acitivty by the phenanthroindolizidine alkaloids pergularinine and tylophorinidine: The in vitro cytotoxicity of these plant alkaloids and their potential as antimicrobial and anticancer agenta. Toxicol. In Vitro 14:53-59.

SHEELEY, S. E., and RAYNAL, D. J. 1996. The distribution and status of species of Vincetoxicum in eastern North America. Bull. Torrey Bot. Club 123:148-156.

Smith, L. L., Ditommaso, A., and GreipsSon, S. 2008. Effects of arubscular mycorrhizal fungi on the exotic invasive vine pale swallow-wort (Vincetoxicum rossicum). Invasive Plant Sci. Mgmt. $1: 142-152$

Smith, L. L., Ditommaso, A., Lehmann, J., and Greipsson, S. 2006. Growth and reproductive potential of the invasive exotic vine Vincetoxicum rossicum in Northern New York State. Can. J. Bot. 84:1771-1780.

ST. DenIS, M., and CAPPUCCINO, N. 2004. Reproductive biology of Vincetoxicum rossicum (Kleo.) Barb. (Asclepiadaceae), an invasive alien in Ontario. J. Torrey Bot. Soc. 131:8-15.

Staerk, D., Christensen, J., Lemmich, E., DuUs, J., Olsen, C. E., and JAROSZEWSKI, J. W. 2000. Cytotoxic activity of some phenanthroindolizidine N-oxide alkaloids from Cyanchum vincetoxicum. J. Nat. Prod. 63:1584-1586.

Staerk, D., Lykkeberg, A. K., Christensen, J., Budnik, B. A., ABE, F., and JAROSZEWSKI, J. W. 2002. In vitro cytotoxic activity of phenanthroindolizidine alkaloids from Cyanchum vincetoxi- cum and Tylophora tanakae against drug-sensitive and multidrugresistant cancer cells. J. Nat. Prod. 65:1299-1302.

Staerk, D., Nezhad, K. B., Asili, J., Emami, S. A., Ahi, A., SAIRAFIANPOUR, M., and JaroszeWSKI, J. W. 2005. Phenanthroindolizidine alkaloids from Vincetoxicum pumilum. Biochem. System. Ecol. 33:957-960.

Streibig, J. C., Rudemo, M., and Jensen, J. E. 1993. Dose-Response Curves and Statistical Models. pp. 29-55 in J. C. STREIBIT and P. KUDSK (eds). Herbicide Bioassays. CRC Press, Boca Raton, FL.

Tewksbury, L., Casagrande, R. A., and Gassmann, A. 2002. 16. Swallow-worts. pp. 209-216 in R. VAN DREISCHE, S. LYON, B. BLOSSEY, M. HODDLE, and R. REARDON (eds). USDA Forest Service Publication FHTET-2002-04, Morgantown, WV.

Thorpe, A. S., Thelen, G. C., Diaconu, A., and Callaway, R. M. 2009. Root exudate is allelopathic in invaded community but not in native community: field evidence for the novel weapons hypothesis. J. Ecol. 97:641-645.

USDA, Natural Resource Conservation Service. 2009. The PLANTS Database (http://plants.usda.gov). National Plant Data Center, Baton Rouge, LA 70874-4490 USA.

WEIR, T. L., BAIS, H. P., and VIVANCO, J. M. 2003. Intraspecific and interspecific interactions mediated by a phytotoxin, (-) catechin, secreted by the roots of Centaurea maculosa (spotted knapweed). J. Chem. Ecol. 29:2397-2412.

WEIR, T. L., BAIS, H. P., and VIVANCO, J. M. 2009. Retraction noteIntraspecific and interspecific interactions mediated by a phytotoxin, (-) catechin, secreted by the roots of Centaurea maculosa (spotted knapweed). J. Chem. Ecol. 35:860.

WiegreBe, W., BudzikieWICZ, H., and FARBER, L. 1970. Aklaloide aus Cyanchum vincetoxicum (L.) Pers. 3. Mitt.: 14-hydroxy-2,3,6trimethyoxy-9,11,12,13,13a,14-hexahydro-dibenzo(f,h)-pyrrolo (1,2b)-isochinolin. Arch. Pharm.(Weinheim) 303:1009-1012.

Wiegrebe, W., FABER, L., Brockman Jr., H., BudZIKIEWIEZ, H., and KRUGER, U. 1969. Alkaloide aus Cynanchum vincetoxicum (L.) Pers. Liebigs Ann. Chem. 721:154. 